\title{
Covid-19 Sürecinin Sosyal Medyaya Yansıması (Bir Meta-Sentez Çalışması)
}

\author{
İsmail Baydili (Öğr. Gör. Dr.)
}

iD Fırat Üniversitesi Teknik Bilimler Meslek Yüksekokulu ibaydili@firat.edu.tr

Başvuru Tarihi: 23.02.2021

Yayına Kabul Tarihi: 02.05.2021

Yayınlanma Tarihi: 30.07.2021

https://doi.org/10.17680/erciyesiletisim.885179

\section{Öz}

Zaman ve mekân zorunluluğunu ortadan kaldıran sosyal medyanın kullanımı, her geçen gün biraz daha artmakta ve kullanım amaçları biraz daha genişlemektedir. Covid-19 ile ilgili bilgi edinmek ve Covid-19'un oluşturduğu kaygıları gidermek isteyen bireyler sosyal medya ortamlarında merak ettikleri sorulara cevap aramaktadır. Bu durum sosyal medya platformları üzerinde sağlık iletişimi ile ilgili ciddi bir bilgi alışverişinin yaşanmasını sağlamaktadır. Sosyal medyanın pandemi süreci ile ilişkisini inceleyen çok sayıda çalışma yapılmıştır. Bu çalışma, sosyal medya ve Covid-19 pandemisi arasındaki ilişkiyi ele alan çalışmaların nitel verilerini birleștirerek kümülatif bir sonuç elde etme amacındadır. Çalışmada nitel verileri değerlendirmeye uygun ve nitel araştırma deseni içinde yer alan meta-sentez yöntem kullanılmıștır. Araștırmaların analizi sonucunda elde edilen veriler araştırmaların sınırlı amaçlar ve sınırlı sonuçlar etrafında birleştiğini göstermiştir. Ayrıca kullanılan yöntemlerde de çeşitliliğin düşük olduğu anlaşılmıştır. Konunun önemi ve genişliği düşünüldüğünde araştırmaların amaçlarının daha çeşitlilik göstermesi gerekmektedir. Araştırmalarda, yeni araștırmalara yol gösterecek, alana yön verecek daha güçlü önerilerin de yer alması gerekmektedir. Ayrıca sağlık iletişiminde yaşanan bilgi kirliliği sorununa çözüm getirecek daha fazla çalışmaya ihtiyaç vardır.

Anahtar Kelimeler: İletişim Bilimleri, Covid-19, Sosyal Medya, Meta-Sentez, Sağlık İletişimi. 


\title{
Reflection of the Covid-19 Process on Social Media (A Meta-Synthesis Study)
}

\author{
İsmail Baydili (Lect. Ph.D.)
}

iD Firat University Vocational School of Technical Sciences ibaydili@firat.edu.tr

Date Received: 23.02.2021

Date Accepted: 02.05.2021

Date Published: 30.07.2021

https://doi.org/10.17680/erciyesiletisim.885179

\begin{abstract}
Individuals who want to learn about Covid-19 and address the concerns caused by Covid-19 are looking for answers to their questions on social media to satisfy their curiosity. This enables a serious exchange of information about health communication on social media platforms. There have been numerous studies examining the relationship of social media with the pandemic process. This study is aims to achieve a cumulative result by combining qualitative data from studies that address the relationship between social media and the Covid-19 pandemic. In the study, meta-synthesis method suitable with the evaluation of qualitative data and in qualitative research pattern was used. The data obtained from analysing the researches showed that the studies were converged around limited purposes and limited results. It was also understood that there was low diversity in the methods used. Considering the importance and amplitude of the subject, the purposes of researches should have been more diverse. The researches should also include stronger recommendations that will guide new research and guide the field. In addition, more work is needed to solve the problem of information pollution in health communication.
\end{abstract}

Keywords: Communication Sciences, Covid-19, Social Media, Meta-Synthesis, Health Communication. 


\section{Giriş}

İlkel yöntemlerle başlayan iletişim süreci, teknolojik gelişmelerle birlikte her geçen gün ilerlemiştir. Özellikle internetin yaşamımıza girmesi ${ }^{1}$ ile iletişimsel dönüşüm yaşanmıştır. Bu dönüşüm toplumsal algının da değişmesini, yeniden şekillenmesini sağlamıştır. Yani, içinde bulunduğumuz çağda meydana gelen gelişmeler sadece iletişimi dönüştürmemiş aynı zamanda sosyal, ekonomik ve kültürel yaşamda da yeni yönelimlerin gelişmesine katkıda bulunmuştur (Öztürk \& Talas, 2015, s. 102). Geçmişe göre daha özgürleștirici politikalarla neredeyse her ortam ve zaman, bireyin iletișim ihtiyacını giderebilmesini olanaklı hale getirmiştir (Kırık, 2017, s. 231). Binark ve arkadaşlarına göre (2009, s. 25) bu yeni süreç, mekân ve zaman kavramının yapıbozuma uğramasına neden olmuştur (Akt: Babacan, Haşlak, \& Hira, 2011, s. 66). Bahsi geçen yapıbozumun ortaya çıkışı analiz edildiğinde ise sınır ötesi bir dünya kurgusunun varlığı ile karşılaşmaktayız (Alemdaroğlu \& Demirtaş, 2004, s. 206). Bireylerin sınır ötesi kimlik kazanması farklı bir ifade ile sınırları aşan bir güce sahip olması bireylerde duygu, düşünce, inanç ve davranışların değişimini gerçekleştirmiştir (Arğın, 2019, s. 167). Böylece sınıflar üstü, nesiller üstü ve cinsiyetler üstü yeni insan diye nitelendirebileceğimiz (Özkök, 2013; Ete \& Taştan, 2014, s. 88; Babacan M. E., 2014, s. 154) yeni bir algı ve yaşam başlamıştır.

Yeni insanın sosyal yaşamı da yeni ortama uygun hale gelmiş ve sosyal medya diye ifade edebileceğimiz yeni nesil sosyal ortamların doğmasını sağlamıştır. Sosyal medya konusuna giriş yaparken belirtilmesi gereken en önemli nokta "sosyal medya" ile "sosyal ağ" arasındaki farktır. Sosyal medya bir iletişim kanalı, sosyal ağ ise birkaç taraf arasında bilgi paylaşımını içeren iki yönlü doğrudan iletişimdir (Moorhead, ve diğerleri, 2013, s. 2-3) Kaplan ve Haenlein (2010, s. 59-68) sosyal medyayı "Web 2.0'ın ideolojisini ve teknolojisini temel alan ve kullanıcı tarafından oluşturulan içeriğin yaratılmasına ve değiş tokuşuna izin veren bir grup internet tabanlı uygulama" olarak ifade etmiştir (Akt: Moorhead, ve diğerleri, 2013, s. 2-3). Benzer bir ifadeyi Evers ve arkadaşları da (2013, s. 265) çalışmasında aktarmıştır. Kirtiş ve Karahan ise (2011) sosyal medyayı kullanıcıların iletişim kurmalarına, içerik paylaşmalarına izin veren ve kişisel yorumlar gibi aktivitelere dayalı sosyal ağ olarak tanımlamıştır.

Günümüz insanlarının alışkanlığı olan sosyal medya her kültürden, ekonomik düzeyden, yaşam şeklinden insanların taleplerini karşılayan bir ortam şeklindedir. Sürekli güncellenebilme, çoklu kullanımı destekleme, sanal paylaşım olanağı (Vural \& Bat, 2010, s. 3349) etkileşim imkânı, hipermetin yapısı (Binark, 2014, s. 16) anlık olması, içeriğin kullanıcı tarafından (amatör) üretilmesini olanaklı hale getirmesi, mobil etkileşime açık, öngörülemez ve melez yapısı (Şener, 2013, s. 6) gibi özellikleri bu yeni ortamın cazibesini güçlendirmektedir. İnsanlar bu yeni mecrada fikirlerini ifade edebilmekte, tartışabilmekte ve geliştirebilmektedir. Bunların yanı sıra görsel ve işitsel materyalleri de paylaşabilmektedir (Vural \& Bat, 2010, s. 3349). Tüm bu özellikleri göz önünde bulundurduğumuzda sosyal medya bireye sadece iletişim sağlama avantajı sunmamakta, bununla beraber bilgi edinme, oyun oynama, araștırma, inceleme yapabilme ve bireylerin neredeyse her alandaki ihtiyaçlarını karşılayabilmesine de olanak tanımaktadır (Hazar, 2011, s. 153).

Günümüzde yaygın olarak kullanılan teknoloji tabanlı eğitimin bir parçası olarak görünen sosyal medya (Öztürk \& Talas, 2015) çok sayıda ve farklı türde bilgilere eşzamanlı yahut eşzamansız ulaşılabilme imkânı sunmaktadır. İnternet aracılığı ile sunulan bu imkânın bilgi edinmedeki gücü ve cazibesi sürekli artırmaktadır (Yılmaz, 2016, s. 967). Fakat çağımızın en çok tercih edilen sosyalleşme aracı olan sanal dünya eğitim ve bilgi 
edinme adına kullanıcılarına çok büyük bir imkân sunarken beraberinde bazı riskleri de getirmektedir. Bilginin doğruluğu teyit edilmeden, özellikle mobil ağların hızlı yayma gücü de kullanılarak sosyal ağlar üzerinden yanlış bilgi yayılabilmektedir. Bu yayılım normal bir yayılımın kat kat üstündedir. Haber yayılım hızı açısından konuyu araştıran Karagöz (2018, s. 678) sanal ağların, geleneksel medyadan 6 kat daha hızlı bir şekilde haberi yaydığını ifade etmiştir. Bu yayılım hızı düşünüldüğünde sosyal ağlarda dolaşan hatalı bir bilginin oluşturabileceği tahrifat oldukça zor düzeltilebilecektir.

Her bireyin ihtiyacının farklı olduğunu düşündüğümüzde bu ihtiyaçlara yönelik bilgi doyumların sağlanabilmesi için ciddi bir veri kaynağına ihtiyaç söz konusudur. İnternet ortamında da böyle bir veri yığının varlığı açıktır². Rakamla ifade edilmesi gerekirse, 2014 yılında 500 milyon civarında olan internetteki web sitesi sayısı (Yüksel, 2014, s. 126) bugün (2021-Ocak) “Internetlivestats" verilerine göre 1.828.000.000'un üzerindedir. Böyle bir kanal genişlemesinin oluşturduğu bilgi yığını düşünüldügünde bilgi kirliliği diye ifade edebileceğimiz sorunun ciddiyeti daha anlaşılır olmaktadır. İnternet yığını içindeki kimi bilgilerde dezenformasyon, kimi bilgilerde ise misenformasyon sonucunda (Tunç, 2010, s. 248) doğru bilgiye ulaşmada sorunlar yaşanabilmektedir. Yahut zit bilgilerle hangisinin doğru hangisinin hatalı olduğu karmaşası yaşanabilmektedir. $\mathrm{Bu}$ hatalı bilgilerin kontrol edilebilmesi (teyit edilebilmesi) için geliştirilmiş uygulamaların da (Kavaklı, 2019) varlığı olmakla birlikte henüz tüm kullanıcıların böyle uygulamaları kullanabilecek medya okuryazarlığına sahip olmadığı da bilinen bir gerçektir. Özellikle sosyal medya daha özgürlükçü ve demokratik bir alan olmasından dolayı dezenformasyon ve misenformasyona daha açık bir hal almaktadır. Sıradan kullanıcıların içerik üretici konuma gelebilmeleri de bu durumun yaşanmasında oldukça etkili nedenlerden birisidir (Kavaklı, 2019, s. 665). Bu açıdan değerlendirdiğimizde ifade etmemiz gereken bir diğer kavram da "post-truth" kavramıdır. Duyguların ve kişisel kanaatlerin, rasyonel gerçeklerden daha etkili olduğunu anlatan Post-truth kavramı, Oxford sözlüğüne göre 2016 yılında \%2000 kullanımı artmış ve yılın kelimesi seçilmiştir (Şimşek, 2018, s. 2). Sosyal medyanın içinde bulunduğu bugünkü durumu açıklamada sıklıkla kullanılan posttruth, yeni dönemin yeni gerçekliğidir.

Sağlık iletişimi, sosyal medya aracılığı ile sıklıkta aktarılan konulardan birisidir. Sosyal medyada aktarılan ve doğruluğundan şüphe edilen belki de en önemli konuların başında sağlık bilgileri gelmektedir. Moorhead ve arkadaşları (2013, s. 1) sağlık iletişiminin sosyal medya ile aktarılmasının önemini çeşitli başlıklar altında toplamışlardır. Moorhead ve arkadaşlarına göre sağlık iletişiminin sosyal medya aracılığı ile aktarılmasında başkaları ile iletişim geliştirme, özel bilgilere erişimin daha kolaylaşması, sağlı ile ilgili bilgilerin genişlemesi, sosyal ve duygusal desteğin artması ve sağlık politikalarını etkileme potansiyeli açısından önemlidir. Bu başlıklara kullanıcı sayısına bağlı olarak bilgi paylaşımının artması ve süreçlerin hasta kontrolü ile daha demokratik ilerlemesine olanak tanıması eklenmelidir (Chou, Hunt, Beckjord, Moser, \& Hesse, 2009, s. 2).

Sosyal medya geniş ve çevrimiçi birçok aracı içerir ve bireyler arasında bir bağlılık duygusu oluşturur. Böyle bir ağın içinde tüketiciler bilgilerini paylaşır ve tercihen anonimlik içinde uzak mesafelere ve geniş kitlelere bilgilerini aktarır. Bu sebepler sosyal medyanın sağlık iletişiminde popüler bir hale gelmesini sağlar (Korda \& Itani, 2013, s. 16). Popülerleşen sağlık bilgileri sayesinde yeni kullanıcıların da yeni bilgiler paylaşmasını teşvik eder. Böylece başarılı bir sosyal medya erişim döngüsü oluşturulur (Korda \& Itani, 2013, s. 20-23). Ayrıca sosyal medyanın hızı ve erişim gücü düşünüldüğünde mevcutta var olan 
hatalı bilgilerin düzeltilmesinde de önemli bir kaynak olarak kullanılabilir yapıya sahiptir (Bode \& Vraga, 2018, s. 1131-1132).

Hasta, sağlıkçı ve toplum arasında iletişim kurmada büyük bir kolaylık sağlayan sosyal medyada sağlık bilgilerinin aktarılmasında; bilgi kalitesi, bilgi güvenliği ve de hastaların özel durum mahremiyeti önem taşımaktadır. Bu alana dair çalışmalarda da bu başlıklar sıklıkla vurgulanmıştır (Moorhead, ve diğerleri, 2013, s. 2). Tüm bilgilerde olduğu gibi sağlık bilgilerinde de eksik ya da yanlış bilgilerin önüne geçilmesi oldukça önemlidir. Sağlık bilgilerindeki hatalı veriler birçok insanın yaşamını tehdit eden bir duruma dönüşebilmektedir. 2015 yılında Brezilya'da yaşanan "zika virüsü" üzerine yapılan sosyal medya çalışmalarında elde edilen verilere göre virüs ile ilgili yayılan yanlış bilgilerin çoğunun sosyal medyadan kaynaklandığı anlaşılmıştır (Bode \& Vraga, 2018, s. 1131-1132). Zika virüsünde yaşanan durum hemen hemen birçok sağlık konusunda da yaşanmaktadır. $\mathrm{Bu}$ nedenle sosyal medyadaki sağlık bilgilerinin, bilgi kalitesi dikkatle incelenmelidir.

Her geçen gün yeni medyanın daha ön plana çıkması sosyal medya ile yapılan çalışmaların da artmasını sağlamaktadır. Tüm olumsuz düșünce ve yorumlara rağmen yapılan araştırmalar bazı sağlık konularının çevrimiçi iletişim ile daha etkin bir çerçevede ilerlediğini ve istenilen sonuçların daha hızlı alındığını göstermektedir. Ayrıca sosyal medyanın sağlık iletişiminde davranış değişikliklerine katkı sağladığı da çalışmalarla ortaya konulmuştur (Korda \& Itani, 2013, s. 16-17). İnternet ve sosyal medya kullanım süreleri değerlendirildiğinde sağlı ve sosyal medya üzerine yapılmış çalışmalar sosyal medyanın hayatımızda kapladığı yere göre daha sınırlıdır. Bu alan ile ilgili daha çok araştırmaya ihtiyaç duyulmaktadır.

Sosyal medyanın sağlık iletişimindeki etkinliği Covid-19 salgınında da gözler önüne serilmiştir. Aralık 2019'da (www.who.int, 2021) şiddetli akut solunum sendromuna neden olan virüsle yapısal olarak ilişkili yeni bir koronavirüs tespit edilmiştir (Fauci, Lane, \& Redfield, 2020, s. 1268). Hastalığın semptomları (öksürük, yorgunluk ve solunum yolu enfeksiyonlarının diğer belirtileri) incelendiğinde sıradan bir grip gibi görünmektedir. Genellikle bu belirtiler virüs ile temastan sonraki ilk hafta ortaya çıkmaktadır (Velavan \& Meyer, 2020, s. 278). Fakat yapılan ilk araştırmalarda bu virüsü sıradan bir gripten ayıran en önemli nokta fark edilmiştir. Virüse yakalanan hastalarda ilk 28 gün içinde ciddi rakamlarda hayatını kaybeden insan vardır. Hayatını kaybedenlerin ortak özelliği ise atlatanlara göre daha yaşlı olmalarıdır. Ayrıca virüsün akut böbrek hasarı, karaciğer fonksiyon bozukluğu, ARDS problemlerine de yol açtığı anlaşılmıştır (Yang, ve diğerleri, 2020, s. 475). Tüm bu bilgiler insanlarda bir korku ve panik yaşanmasına neden olmuş ve ortaya çıkan bu atmosfer sosyal medyaya da yansımıştır. Covid-19 ile ilgili birçok sosyal medya paylaşımı gerçekleştirilmiştir. Sosyal medya paylaşımları sonucu ortaya çıkan yanıltıcı söylentiler, komplo teorileri, korku tacizleri ve ırkçılık da ciddi oranda gözlemlenmiştir. Öyle ki Uzak Doğulu turistler dünyanın birçok yerinde Çinli olabilmeleri ihtimali ile viral ırkçılığa bile maruz kalmıştır (Depoux ve diğerleri, 2020, s. 1-2). Oluşan korku havası tüm bunların yanında gelecekte daha kötü şeylerle karşılaşma tereddüttü oluşturmuştur. Bu tereddütle insanlar ihtiyaç dışı satın alma eğilimine bile sürüklenmiştir (Naeem, 2021, s. 1). Virüsten kaçınma ya da tedavisi ile ilgili de birçok sosyal medya verisi ortaya çıkmıştır. Doğruluğu ispatlanmamış tedavi yöntemleri, yeme içme bilgileri ve virüs ile ilgili diğer hatalı bilgiler virüsün kendi zararının ötesinde bir etki oluşturmuştur (Radwan \& Radwan, 2020). Bu panik havasının ruh sağlığında neden olduğu bozulmalar da gözlemlenmiş ve araştırılmaya başlanılmıștır. Öncelikli çalışmalar kitle travmasına 
yönelikken, travma sonrası stres bozukluklarındaki artış ihtimali de araştırmacıların dikkatini çeken konulardan olmuştur (Gao ve diğerleri, 2020, s. 1-2).

Özetle sosyal medya aracılığı ile aktarılan sağlık bilgilerindeki hatalar ciddi problemlerin doğmasına insanların psikolojik travmalar geçirmesine neden olmuştur. Sosyal medya bu durumun oluşmasında büyük bir etkiye sahiptir. Bu etki birçok araştırmacı tarafından bilimsel olarak analiz edilmiştir. Covid-19 ile ilgili yapılan bilimsel çalışmaların çokluğu tıpkı sağlık bilgilerindeki gibi bir karmaşaya neden olmaktadır. Bilginin büyümesi için yapılan çalışmaların çeşitli yöntemlerle birleştirilmesi gerekmektedir. Ayrıca Covid-19 pandemisi sosyal medyanın da sağlık bilgilerini iletmesi yönünden ciddi bir sınav olmuştur. Sosyal medyanın oluşturduğu bu bilgi akışının doğru şekilde değerlendirilmesi insanlığa önemli bir fayda sağlayacaktır. Aksi takdirde ortaya çıkan panik ve kaosun daha artmasına neden olacaktır.

\section{Yöntem}

Çalışmada nitel araştırma deseni kullanılmıştır. Nitel araştırma "nicelleştirilemeyen" yöntem ve tekniklerin bir çatı nitelemesidir (Güçlü, 2019, s. 18). Nitel araștırma deseninin değerlendirme, yorumlama ve eleștirmeye yönelik yapısı metinlerdeki/ belgelerdeki söylemleri çözümlemek için uygun bir yöntemdir (Berger, 2000, s. 14; Geray, 2004, s. 54).Çalışmada akademik dokümanlar (makaleler) incelenmiştir. Doküman inceleme, önceden oluşturulmuş her türlü belgenin incelenmesine olanak tanır. Doküman inceleme hem nicel hem de nitel çalışmalara uygun bir veri toplama tekniğidir (Sönmez \& Alacapınar, 2019, s. 198).

Doküman incelemesi sonucu elde edilen veriler meta-sentez ${ }^{3}$ yöntem ile değerlendirilmiştir. Artan nitel araştırmaların kümülatif bir değerlendirilmesinin yapılmasına olan ihtiyacı gideren meta-sentez yöntem, işlenmiş verileri bir araya toplayarak tekrar işleme girişimidir. Böylece çalışmalarda kazanılmış perspektiflerin geliştirilmesi amaçlanmaktadır. Meta-sentez ile spesifik bir konuda değerlendirmelerin ötesinde bir değerlendirme geliştirilir. Meta-sentez ile farklı çalışmalardaki çelişkili bulgular belirlenebilir. Olguların daha kapsamlı tanımları yapılabilir (Timulak, 2007, s. 305). Meta-sentezde belirli kriterlere bağlı kalarak aynı alan, konu veya tema üzerinde yapılmış çalıșmalar yorumlanabilir, nitel bulgu ve yorumlar birleştirilebilir (Au, 2007; Campbell, vd. 2003; Çalık \& Sözbilir, 2014; Walsh ve Downe, 2005; Zimmer, 2006; Dinçer, 2018, s. 180).

Schreiber ve arkadaşları (1997) meta-sentezin teori oluşturma, teori açılama ve teori geliştirme şeklinde özetlediği üç amacından bahseder. Meta-sentez iki hedef doğrultusunda gerçekleştirilir. İlk hedefi araştırılan bir olgunun belirsizliklerini gidermek, farklılıklarını ortaya koymak ve daha kapsamlı bir tanımını gerçekleştirmektir. Diğer hedefi ise araștırma yönteminin bulgular üzerindeki etkisinin bir değerlendirmesini sağlamaktır (Akt: Timulak, 2009, s. 593).

Meta-sentez yöntemde ilk aşama veri taramadır. İkinci aşama ise dâhil etme aşamasıdır (Field \& Gillett, 2010, s. 665). Araştırmaya dâhil edilecek çalışmalar belirlenmiş kriterlere göre tasnif edilir (Timulak, 2007, s. 307). Buradaki kriterler dikkatle belirlenmelidir. Field ve Gillett (2010, s. 665-670) kriterlerin dikkatle seçilmesi gerektiğini değișik bir metafor ile izah etmiştir. Field ve Gillett'e göre kötü bir çalışma tüm iyi çalışmaları mahvedebilir. Beyaz çamaşırların içinde kırmızı bir çamaşırı yıkamak gibi tüm çalışmanın yapısını bozabilir. Bu nedenle dahil etme kriterleri dikkatle uygulanmalıdır. Araştırmaya dâhil 
edilen çalışmalar belirlenmiş kriterlere göre değerlendirilir ve yorumlanır. Meta-sentez yöntem henüz emekleme aşamasında olan bir yöntem olarak değerlendirilmektedir.

\section{1. Çalışmaya Dâhil Etme Kriterleri ve Sınırlııklar}

Araștırmaların çalışmaya dâhil edilmesi için aşağıdaki kriterler belirlenmiştir;

- 2020 ve sonrası yayınlanmış olmak

- Covid-19 konusunu işlemiş olmak

- Dergipark sisteminde erişilebilir olmak

- Türkiye ile ilgili ve Türkçe olmak

- Sosyal medya alanında çalışmış olmak

- Tam erişim izinli olmak

- Anahtar kelimelerinde yeni medya, sosyal medya, dijital medya, covid-19 ifadelerinden en az birini barındırmak.

Araştırmada ele alınan çalışmalar 2020 Ocak tarihinden sonra yayınlanmış "Dergipark" sisteminden erişilebilinen sosyal medya ve Covid-19 üzerine gerçekleștirilmiş araştırmalardır. Çalışmada incelenecek araştırmaların belirlenmesi için Dergipark sisteminden "covid-19" ve "medya" anahtar kelimeleri ile arama gerçekleștirilmiştir. Arama sonucu elde edilen 107 araștırmanın tamamı indirilerek incelenmek istenilmiş fakat 105 araştırma indirilebilmiştir. İndirilen 105 araştırma ilk olarak başlık, özet ve anahtar kelimeler açısından incelenmiş ve çalışmanın genel yapısına uygun olduğu görülen 32 araştırma daha detaylı incelenilmek üzere ayrıștırılmıştır. Bir sonraki değerlendirmede, araştırmalar dikkatle incelenmiş ve içlerinde yeni medya ya da sosyal medya olmayan, geleneksel medyayı ele alan çalışmalar da tasnif dıșı bırakılmıştır. 17 uygun araștırma ile çalışmanın sınırlılıkları içinde kalan araştırmalar netleştirilmiştir. Çalışmada zaman sınırlılığı olarak 2020 tarihinin seçilmesi Covid-19 pandemisinin başlangıç tarihinden dolayıdır. Dergipark sınırlılığının seçilmesi ise TUBİTAK ve ULAKBİM tabanının belirli bir akademik kaliteyi temsil etmesinden ötürüdür. Araştırmaların sınırlandırılmasında kullanılan bir diğer kriter, Türkiye ile ilgili ve Türkçe yapılmış araştırmaların dahil edilmesidir. Türkiye dışındaki yerlerde yapılmış araştırmaların, çalışmanın ağırlıklı desenini bozacağına olan inançla böyle bir sınırlandırılma getirilmiştir.

\subsection{Amaç ve Analiz Konuları}

2019'un sonundan beri tüm dünyada ciddi sorunlara neden olan Covid-19 ile ilgili çağımızın en aktif iletişim aracı olarak değerlendirebileceğimiz sosyal medya platformlarında hem olumlu hem de olumsuz birçok bilginin aktarıldığı, tüm kullanıcılar tarafından görülmüştür. Sosyal medyanın dünyadaki tüm insanların hayatını bu kadar derinden etkileyen bir sağlık problemi ile ilgili oluşturduğu algılar bazen hastalığın gerçeklikleri ile çelişmektedir. Bu karmaşık durum birçok bilim insanın dikkatini çekmiş ve sosyal medya üzerindeki Covid-19 paylaşımları hakkında birçok çalışma yapılmıştır. Her biri farklı bir bakış ve farklı bir amaçla yapılmış birçok çalışmada birçok önemli tespit ve sonuç paylaşılmıştır. Bu çalışmadaki temel amaç, bu süreçte yapılan bilimsel çalışmaları bir araya getirerek birikmiş bir sonuç oluşturmaktır.

Araştırmaların meta-sentez yöntem ile incelenebilmesi, tüm çalışmalara eşit bir bakıșın geliştirilebilmesi ve eşit verilerin toplanabilmesi için çalışmalarla ilgili temel bir tabloya ihtiyaç duyulmuştur. Bu bağlamda çalışmalarda ilk dikkat edilen unsurların yer aldığı ilgili tabloda (Tablo 2) şu bilgiler aktarılmıştır; 
- Çalışma deseni

- Çalışma yöntemi

- Çalıșma alanı

- Sinirlılıklar

- Anahtar kelimeler

Çalışmada cevap aradığımız sorularda dikkat edilen nokta çalışmaların genelini yansıtacak, toplam bir sonuca ulaştırmayı sağlayacak kriterleri belirlemektir.

Araştırma Soruları:

- Araştırmalar neyi amaçlamıştır?

- Yapılan araştırmalarda öne çıkan sonuçlar nelerdir?

- Yapılan araştırmalarda daha sonraki çalışmalara öneriler nelerdir?

Araştırmalar incelenirken karmaşanın önüne geçilmesi için araştırmalara Ar-01 ile Ar17 arasında kodlar verilmiștir. İlgili kodların hangi araștırmayı temsil ettiği aşağıdaki tabloda gösterilmiştir.

Tablo 1. Kodlarla Temsil Edilen İlgili Araştırmalar*

\begin{tabular}{|c|c|}
\hline Kod & Araştırmalar \\
\hline Ar-01 & $\begin{array}{l}\text { Subölen, S. (2020). Covid } 19 \text { Pandemisi Sürecinde Stresle Baş Etme Yöntemi Olarak } \\
\text { Sosyal Medyada Mizah Olgusu: cezmikalorifer ve saykodelipaylasimlarr İsimli Instagram } \\
\text { Hesaplarının Analizi. AJIT-e: Bilişim Teknolojileri Online Dergisi 11.42: 123-142. }\end{array}$ \\
\hline Ar-02 & $\begin{array}{l}\text { Dikmen, M. (2021). COVID-19 Pandemisinde Üniversite Öğrencilerinin Depresyon } \\
\text { Düzeyleri ile Sosyal Medya Bağımlııkları Arasındaki Ilişki: Bir Yapısal Eşitlik } \\
\text { Modeli, Bağımlılık Dergisi, Journal of Dependence, } 22 \text { (1) : 20-30 }\end{array}$ \\
\hline Ar-03 & $\begin{array}{l}\text { Koç, M. A. (2020). Covid-19 Salgınının Yarattığı Küresel Kriz Bağlamında Sosyal Medyada Kriz } \\
\text { Yönetimi: Türk Hava Yolları Örneği, Avrasya Sosyal ve Ekonomi Araştırmaları Dergisi, 7(7), 190-200. }\end{array}$ \\
\hline Ar-04 & $\begin{array}{l}\text { Tam, M. S. (2020). Covid-19 Süresince TC Sağlık Bakanlığı YouTube Kanalına } \\
\text { İzleyici Dönütleri, Düşünce ve Toplum Sosyal Bilimler Dergisi, (3), 116-139. }\end{array}$ \\
\hline Ar-05 & $\begin{array}{l}\text { Karataş, Z. (2020). COVID-19 Pandemisinin Toplumsal Etkileri, Değişim ve } \\
\text { Güçlenme”, Türkiye Sosyal Hizmet Araştırmaları Dergisi, 4(1), 3-17. }\end{array}$ \\
\hline Ar-06 & $\begin{array}{l}\text { Akgül, M. (2020). Çevrimiçi Ortamlarda Nefret Söylemi: Ekşi Sözlük’te } 65 \text { Yaş Üstü Sokağa } \\
\text { Çıkma Yasağı Tartışmaları, İletişim Kuram ve Araştırma Dergisi, 2020(51), 57-78. }\end{array}$ \\
\hline Ar-07 & $\begin{array}{l}\text { Özoran, B. A. (2020). Covid-19 Salgınında Markaların Twitter Kullanımları Üzerine Bir İnceleme, } \\
\text { Yüzüncü Yıl Üniversitesi Sosyal Bilimler Enstitüsü Dergisi, (Salgın Hastalıklar Özel Sayısı), 429-458. }\end{array}$ \\
\hline Ar-08 & $\begin{array}{l}\text { Yersel, B. Kalkan, B. ve Özer, A. Ç. (2020). Kim Paylaşıyor? İnfodeminin Önüne } \\
\text { Geçmek için Alan Uzmanı Kanaat Önderlerinin Instagram Kullanımları ve Kullanıcı } \\
\text { Etkileşimlerinin Analizi. Avrasya Uluslararası Araştırmalar Dergisi, 8(24), 12-40. }\end{array}$ \\
\hline Ar-09 & $\begin{array}{l}\text { Ateş N. B. ve Baran, S. (2020). Kriz İletişiminde Sosyal Medyanın Etkin } \\
\text { Kullanımı: Covid-19 (Koronavirüs) Salgınına Yönelik Twitter Analizi, Kocaeli } \\
\text { Üniversitesi İletişim Fakültesi Araştırma Dergisi, (16), 64-96. }\end{array}$ \\
\hline Ar-10 & $\begin{array}{l}\text { Bahar, A. (2020). Polislik Perspektifinden Dijital Misenformasyon ve Dezenformasyon: Covid-19 Örnek } \\
\text { Olayı Bağlamında Bir Analiz, OPUS Uluslararası Toplum Araştırmaları Dergisi, 16(30), 2760-2794. }\end{array}$ \\
\hline Ar-11 & $\begin{array}{l}\text { Aydın, A. F. (2020). Post-truth Dönemde Sosyal Medyada Dezenformasyon: } \\
\text { Covid-19 (yeni koronavirüs) Pandemi Süreci, Asya Studies, 4(12), 76-90. }\end{array}$ \\
\hline Ar-12 & $\begin{array}{l}\text { Yeniçıktı, N. T. (2020). Sağlık Bakanlığının Instagram Paylaşımları Üzerinden } \\
\text { Göstergebilimsel Bir İnceleme \#Hayatevesığar, Gaziantep Üniversitesi } \\
\text { Sosyal Bilimler Dergisi, 19(COVID-19 Special Issue), 365-385. }\end{array}$ \\
\hline Ar-13 & $\begin{array}{l}\text { Tanışık, S. (2020). Sosyal Medyada İçerik Üretiminin Markaların İtibarına Olan Etkisi: } \\
\text { Covid-19 Pandemi Sürecinde Koç, Eczacıbaşı ve Arçelik'in Instagram Paylaşım } \\
\text { Analizi, Avrasya Sosyal ve Ekonomi Araştırmaları Dergisi, 7(6), 422-435. }\end{array}$ \\
\hline Ar-14 & $\begin{array}{l}\text { Kirman, F. (2020). Sosyal Medyada Salgın Psikolojisi: Algı, Etki ve Başa } \\
\text { Çıkma, Dünya İnsan Bilimleri Dergisi, 2020(2), 11-44. }\end{array}$ \\
\hline
\end{tabular}




\begin{tabular}{|l|l|}
\hline Kod & Araştırmalar \\
\hline Ar-15 & $\begin{array}{l}\text { Cllızoğlu, G. Y. Dondurucu, Z. ve Çetinkaya, A. (2020). Sosyal Pazarlama Bağlamında } \\
\text { Covid-19 Salgını Sürecinde GSM Operatörlerinin YouTube Reklamlarının Analizi, } \\
\text { Uluslararası Kültürel ve Sosyal Araştırmalar Dergisi (UKSAD), 6(1), 280-299. }\end{array}$ \\
\hline Ar-16 & $\begin{array}{l}\text { Bilgiç, A. ve Akyüz, S. S. (2020). Türkiye'de Covid-19 Pandemisi Döneminde Sağlık } \\
\text { Bakanı Fahrettin Koca'nın Sosyal Medya Kullanımı: Twitter Paylaşımları İçerik Analizi”, } \\
\text { Gaziantep Üniversitesi Sosyal Bilimler Dergisi, 19(COVID-19 Special Issue), 230-243. }\end{array}$ \\
\hline Ar-17 & $\begin{array}{l}\text { Akyüz, S. S. (2020). Yanlış Bilgi Salgını: COVID-19 Salgını Döneminde Türkiye'de Dolaşıma } \\
\text { Giren Sahte Haberler, Akdeniz Üniversitesi İletişim Fakültesi Dergisi, (34), 422-444. }\end{array}$ \\
\hline
\end{tabular}

Tablo 2. Incelenen Çalışmaların Yapısı ile İlgili Bilgiler

\begin{tabular}{|c|c|c|c|c|c|}
\hline Kod & Desen & Yöntem & $\begin{array}{l}\text { İncelediği } \\
\text { Platform }\end{array}$ & Sınırlılıklar & Anahtar Kelimeler \\
\hline Ar-01 & Nicel & $\begin{array}{l}\text { İçerik } \\
\text { Analizi }\end{array}$ & Instagram & $\begin{array}{l}\text { 01.04-01.06 Arası Instagram } \\
\text { Mizah Paylaşımları }\end{array}$ & $\begin{array}{l}\text { Covid-19, Pandemi, } \\
\text { Sosyal Medya, Mizah, } \\
\text { Instagram, Analiz }\end{array}$ \\
\hline Ar-02 & Nicel & $\begin{array}{l}\text { İlişkisel } \\
\text { Tarama }\end{array}$ & Kullanıcılar & $\begin{array}{l}\text { Firat Üniv. } 211 \\
\text { Öğrenci (Anket) }\end{array}$ & $\begin{array}{l}\text { Depresyon, Sosyal Medya } \\
\text { Bağımlılığı, Covid-19 }\end{array}$ \\
\hline Ar-03 & Nitel $^{*}$ & $\begin{array}{l}\text { İçerik } \\
\text { Analizi }\end{array}$ & YouTube & $\begin{array}{l}\text { THY'nin Sosyal Medya } \\
\text { Paylaşımları ve Paylaşımlara } \\
\text { Gelen Yorumlar }\end{array}$ & $\begin{array}{l}\text { Covid-19, Kriz Yönetimi, İtibar } \\
\text { Yönetimi, Türk Hava Yolları }\end{array}$ \\
\hline Ar-04 & Nitel & $\begin{array}{l}\text { İçerik } \\
\text { Analizi }\end{array}$ & YouTube & $\begin{array}{l}\text { 10.03-30.09 Arası Sağlık } \\
\text { Bak. YouTube Kanalındaki } \\
\text { Paylaşımlara Gelen Yorumlar }\end{array}$ & $\begin{array}{l}\text { Covid-19, T.C. Sağlık } \\
\text { Bakanlığı, YouTube, Sağlık } \\
\text { Illetişimi, Sosyal Medya }\end{array}$ \\
\hline Ar-05 & Nicel & $\begin{array}{l}\text { Genel } \\
\text { Tarama / } \\
\text { Betimsel } \\
\text { Araştırma }\end{array}$ & Kullanıcılar & $\begin{array}{l}\text { Sosyal Medya } \\
\text { Kullanan } 520 \text { Kişi }\end{array}$ & $\begin{array}{l}\text { Covid-19 Pandemisi, } \\
\text { Sosyal Etki, Travma Sonrası } \\
\text { Büyüme, Güçlenme }\end{array}$ \\
\hline Ar-06 & $\begin{array}{l}\text { Nitel } \\
\text { /Nicel }\end{array}$ & $\begin{array}{l}\text { İçerik } \\
\text { Analizi }\end{array}$ & Ekşi sözlük & $\begin{array}{l}\text { 21.03-21.04 Arası } 65 \\
\text { Yaş Üstüne Yönelik } \\
\text { Nefret Söylemi } \\
\end{array}$ & $\begin{array}{l}\text { Yeni Medya, Ekşi Sözlük, Nefret } \\
\text { Söylemi, Covid-19, Yaşlılık }\end{array}$ \\
\hline Ar-07 & $\begin{array}{l}\text { Nitel } \\
\text { /Nicel }\end{array}$ & $\begin{array}{l}\text { İçerik } \\
\text { Analizi }\end{array}$ & Twitter & $\begin{array}{l}10 \text { Markanın Paylaşımlarının } \\
\text { İncelemesi }\end{array}$ & $\begin{array}{l}\text { Marka, Tüketim, } \\
\text { Covid-19, Kriz, Twitter }\end{array}$ \\
\hline Ar-08 & Nicel & $\begin{array}{l}\text { İçerik } \\
\text { Analizi }\end{array}$ & Instagram & $\begin{array}{l}\text { Fahrettin Koca ve } 9 \text { Sağlık } \\
\text { Bilimcinin Paylaımlarının } \\
\text { İncelenmesi }\end{array}$ & $\begin{array}{l}\text { Sosyal Medya, Etkileşim, } \\
\text { İnfodemi, Kanaat } \\
\text { Önderi, Covid-19 }\end{array}$ \\
\hline Ar-09 & Nicel & $\begin{array}{l}\text { İçerik } \\
\text { Analizi }\end{array}$ & Twitter & $\begin{array}{l}\text { Türkiye ve AB Sağlık } \\
\text { Bakanlıklarının Twitter } \\
\text { Paylaşım Karşılaştıııması }\end{array}$ & $\begin{array}{l}\text { Sosyal Medya, Kriz } \\
\text { İletişimi, Covid-19 }\end{array}$ \\
\hline Ar-10 & Nitel $^{*}$ & $\begin{array}{l}\text { Betimsel } \\
\text { Alan } \\
\text { Araştırması }\end{array}$ & Twitter & $\begin{array}{l}\text { 11.03-01.06 Arası, Suç } \\
\text { Kabul Edilen Paylaşımların } \\
\text { İncelenmesi }\end{array}$ & $\begin{array}{l}\text { Dijital Polislik, Dijital } \\
\text { Medya, Misenformasyon, } \\
\text { Dezenformasyon, Yeni Normal }\end{array}$ \\
\hline Ar-11 & Nitel & $\begin{array}{l}\text { Betimsel } \\
\text { Analiz / } \\
\text { Doküman } \\
\text { analizi }\end{array}$ & $\begin{array}{l}\text { Sosyal } \\
\text { medya }\end{array}$ & $\begin{array}{l}\text { Doğrulama Platformunun } \\
\text { Covid-19 ile İlgili Sosyal } \\
\text { Medya İncelemeleri }\end{array}$ & $\begin{array}{l}\text { Post-truth, Sosyal } \\
\text { Medya, Dezenformasyon, } \\
\text { Covid-19, Koronavirüs }\end{array}$ \\
\hline Ar-12 & Nitel & $\begin{array}{l}\text { Göster- } \\
\text { gebilim }\end{array}$ & Instagram & $\begin{array}{l}\text { Sağlık Bakanlığı'nın } \\
\text { \#hayatevesığar Hashtag'i } \\
\text { ile Instagramdaki } \\
\text { Paylaşımlarının Analizi }\end{array}$ & $\begin{array}{l}\text { Sosyal Medya, Instagram, } \\
\text { Koronavirüs, Covid-19, } \\
\text { \#hayatevesığar }\end{array}$ \\
\hline Ar-13 & Nitel $^{*}$ & $\begin{array}{l}\text { İçerik } \\
\text { Analizi }\end{array}$ & Instagram & $\begin{array}{l}3 \text { Markanın Pandemi } \\
\text { Sürecindeki Paylaşımları }\end{array}$ & $\begin{array}{l}\text { Sosyal Medya, İçerik } \\
\text { Üretimi, Kurumsal İtibar } \\
\text { Yönetimi, Küresel Salgın }\end{array}$ \\
\hline
\end{tabular}




\begin{tabular}{|c|c|c|c|c|c|}
\hline Kod & Desen & Yöntem & $\begin{array}{l}\text { İncelediği } \\
\text { Platform }\end{array}$ & Sınırlılıklar & Anahtar Kelimeler \\
\hline Ar-14 & Nitel & $\begin{array}{l}\text { İçerik } \\
\text { Analizi }\end{array}$ & $\begin{array}{l}\text { Twitter ve } \\
\text { WhatsApp }\end{array}$ & $\begin{array}{l}\text { Dini Söylemlere Yer Veren } \\
17 \text { Kişinin Twitter ve } \\
\text { WhatsApp Paylaşımları }\end{array}$ & $\begin{array}{l}\text { Covid-19, Pandemi, } \\
\text { Sosyal Medya, Başaçıkma, } \\
\text { Koronavirüs }\end{array}$ \\
\hline Ar-15 & $\begin{array}{l}\text { Nitel } \\
\text { /Nicel }\end{array}$ & $\begin{array}{l}\text { İçerik } \\
\text { Analizi }\end{array}$ & YouTube & $\begin{array}{l}\text { 11.03-11.04 Arası } 3 \\
\text { GSM Operatörünün } \\
\text { Reklamlarının İncelenmesi }\end{array}$ & $\begin{array}{l}\text { Sosyal Pazarlama, Sosyal } \\
\text { Reklam, Covid-19, Sosyal } \\
\text { Medya, YouTube }\end{array}$ \\
\hline Ar-16 & Nicel & $\begin{array}{l}\text { İçerik } \\
\text { Analizi }\end{array}$ & Twitter & $\begin{array}{l}\text { 11.03-10.04 Arası Fahrettin } \\
\text { Koca'nın Paylaşımları }\end{array}$ & $\begin{array}{l}\text { Covid-19, Koronavirüs, } \\
\text { Twitter, Fahrettin Koca }\end{array}$ \\
\hline Ar-17 & Nicel & $\begin{array}{l}\text { İçerik } \\
\text { Analizi }\end{array}$ & $\begin{array}{l}\text { Sosyal } \\
\text { medya }\end{array}$ & $\begin{array}{l}\text { Doğrulama Platformlarının } \\
\text { Sosyal Medyadaki Sahte } \\
\text { Haberleri İncelemesi }\end{array}$ & $\begin{array}{l}\text { Koronavirüs, Covid-19, } \\
\text { İnfodemi, Sahte Haber, } \\
\text { Doğrulama Platformları }\end{array}$ \\
\hline
\end{tabular}

\subsection{Bulgular ve Yorumlar}

Çalışmanın bu bölümünde Covid-19 sürecinin sosyal medya platformlarındaki yansıması konu edinen araştırmaların amaç, sonuç ve önerilerinden elde edilen bulgulara yer verilmiştir.

Tablo 3. Araştırmaların Amaçları

\begin{tabular}{|c|c|}
\hline Kod & Amaçlar \\
\hline Ar-01 & $\begin{array}{l}\text { Araştırmada, kriz sürecinde bireylerin mizahi yaratıcılıkları ile mizahi öğelere karşı verilen } \\
\text { olumlu tepkilerinin (beğeni, paylaşım, görüntüleme) ortaya çıkarılması amaçlanmıştır. }\end{array}$ \\
\hline Ar-02 & $\begin{array}{l}\text { Covid-19 pandemi sürecindeki üniversite öğrencilerinin depresyon düzeyleri ile sosyal medya } \\
\text { bağımlııkları arasındaki ilişki yapısal eşitlik modellemesiyle incelenmesi amaçlanmıştır. }\end{array}$ \\
\hline Ar-03 & Covid-19 sürecinde THY’nin krizi yönetme ve itibarını koruma stratejisini incelemek amaçlanmıştır. \\
\hline Ar-04 & $\begin{array}{l}\text { Sağlık Bakanlığı'nın YouTube kanalındaki Covid-19 içerikli paylaşımlarına } \\
\text { yapılan yorumları ve tepkileri ortaya koymak amaçlanmıştır. }\end{array}$ \\
\hline Ar-05 & $\begin{array}{l}\text { Covid-19'un Türkiye'de görülmesiyle birlikte bireylerde oluşan sosyal etki, değişim ve travma } \\
\text { sonrası büyümenin bazı sosyodemografik değişkenlerle incelenmesi amaçlanmıştır. }\end{array}$ \\
\hline Ar-06 & $\begin{array}{l}\text { Covid-19 tedbirleri kapsamında yapılan } 65 \text { yaş üstü sokağa çıkma yasaklarını konu alan } \\
\text { Ekşisözlük paylaşımlarının nefret söylemi kapsamında incelenmesi amaçlanmıştır. }\end{array}$ \\
\hline Ar-07 & $\begin{array}{l}\text { Türkiye geneli } 10 \text { markanın salgın dönemindeki Twitter paylaşımlarını } \\
\text { araştırmak ve kullanım şekillerini ortaya koymak amaçlanmışır. }\end{array}$ \\
\hline Ar-08 & $\begin{array}{l}\text { Covid-19 sürecinde kanaat önderleri tarafından onaylanan ve sunulan } \\
\text { bilgilerin etkileşim düzeylerini ölçmek amaçlanmıştır. }\end{array}$ \\
\hline Ar-09 & $\begin{array}{l}\text { Covid-19 sürecinde Türkiye ve ABD’nin sosyal medyayı kullanım şekillerinin } \\
\text { karşılaştııılmasıyla, kullanımların etkinliğinin ortaya çıkarılması amaçlanmıştır. }\end{array}$ \\
\hline Ar-10 & $\begin{array}{l}\text { Misenformasyon ve dezenformasyonu üreten motivasyonlara yönelik detayları } \\
\text { ortaya koymak ve çözüm önerileri üretmek amaçlanmıştır. }\end{array}$ \\
\hline Ar-11 & $\begin{array}{l}\text { Covid-19 pandemi sürecinde Türkiye'de faaliyet gösteren teyit.org'un sosyal medyada } \\
\text { dolaşan iddialar hakkındaki incelemeleri ortaya koymak amaçlanmıştır. }\end{array}$ \\
\hline Ar-12 & $\begin{array}{l}\text { Sağlık Bakanlığı'nın Hayatevesığar hashtag'i ile yaptığı Instagram paylaşımlarında } \\
\text { aktarmak istediği mesajları göstergebilim yöntemi ile ortaya koymak amaçlanmıştır. }\end{array}$ \\
\hline Ar-13 & Belirlenen markaların salgın dönemindeki paylaşımlarını ölçmek ve değerlendirmek amaçlanmıştır. \\
\hline Ar-14 & $\begin{array}{l}\text { Koronavirüs salgınını sosyal medyada yapılan paylaşımlardan hareketle } \\
\text { psikolojik algı, etki ve başa çıkma yönünden ele almayı amaçlamıştır. }\end{array}$ \\
\hline Ar-15 & $\begin{array}{l}\text { Türkiye'deki üç GSM operatörünün Covid-19 salgın döneminde YouTube kanallarından yayınladıkları } \\
\text { reklamlardaki değişen yaratıcı strateji/taktik kullanımı ve mesaj içeriklerinin incelenmesi amaçlanmıştır. }\end{array}$ \\
\hline Ar-16 & $\begin{array}{l}\text { Sosyal medyanın kriz döneminde kamu otoriteleri tarafından nasıı kullanıldığını ve } \\
\text { kullanıcıların bu kamu otoritelerine karşı ilgisini ölçmek amaçlanmıştır. }\end{array}$ \\
\hline Ar-17 & $\begin{array}{l}\text { Türkiye'de faaliyet gösteren } 3 \text { doğrulama platformunun } 5 \text { aylık süreçte yayınladıkları yayınlar incelenerek } \\
\text { yanlış bilgilerin yoğunluğu, kaynağı, türü, konuları gibi özellikleri ortaya koymak amaçlanmıştır. }\end{array}$ \\
\hline
\end{tabular}


Bir araştırmayı diğerlerinden ayıran önemli unsurların başında araştırmanın amacı gelir. Bir araştırmanın amacı net ve anlaşılır olmak zorundadır. Elde edilmek istenilen bilginin türüne göre sosyal bilimlerde bilimsel bir araştırmada amaç; sosyal bir olgu ya da olayı keşfetme, betimleme ve ya açıklama olabilir. Bu amaçlar doğrultusunda keşfedici, betimleyici ve açıklayıcı üç araştırma tipinden bahsedilebilir. Araştırmanın amacı araştırmanın yöntemi de dâhil olmak üzere araştırma ile ilgili tüm aşamaları etkilemektedir (www.bingol.edu.tr, 2021). Bu nedenle çalışmada incelenen araştırmaların amaçları da dikkate alınmıştır.

İncelenen araştırmaların amaçları kontrol edildiğinde dört temel alanda yoğunlaştıkları görülmektedir. En sık edinilen amaç sosyal medyanın kullanım şekillerinin analizi olmuştur. Ar-07, Ar-09 ve Ar-16 çalışmaları sosyal medyanın kullanım şeklini incelemeyi amaç edinmiștir. Ar-12 ile Ar-15 ise sosyal medya iletilerinin aktarmak istedikleri mesajlara odaklanmıştır. Ar-13 de yukarıda ifade edilen araştırmalardan pek uzaklaşmamış incelenen markaların sosyal medyadaki paylaşımlarının ölçüm ve değerlendirilmesini amaç edinmiştir. Yani Ar-07, Ar-09, Ar-12, Ar-13 ve Ar-15 sosyal medyanın kullanımı, aktardığı mesajlar ve bu mesajların ölçümü konularına odaklanmıştır. En sık rastlanılan diğer bir amaç ise sosyal medya paylaşımlarının etkileşim durumlarıdır. Ar-01, Ar-04, Ar06 ve Ar-08 sosyal medya paylaşımlarına karşı, sosyal medya kullanıcılarının etkileşimini (beğeni, yorum ve görüntüleme) analiz etmiştir. Araştırmalarda rastlanılan üçüncü amaç ise sosyal medya paylaşımları ile bireylerin psikolojik durumları arasındaki bağlantıyı değerlendirmek olmuştur. Ar-02, Ar-05 ve Ar-14 depresyon, travma ve psikolojik algı açısından bir değerlendirme yapmayı amaç edinmiştir. Yoğunluk kazanan son amaç ise sosyal medya paylaşımlarının doğruluğunu analiz etmektir. Ar-10, Ar-11 ve Ar-17 sosyal medyadaki verilerin ve bilgilerin doğruluğunu analiz etmiştir. Bu dört amacın kapsamına girmeyen Ar-03 ise itibar konusunu araştırmayı amaç edinmiştir. Sosyal medya paylaşımları üzerinden itibar koruma yöntemi analiz edilmiştir.

Tablo 4. Yapılan Araştırmalarda Öne Çıkan Sonuçlar

\begin{tabular}{|c|c|}
\hline Kod & Sonuçlar \\
\hline Ar-01 & $\begin{array}{l}\text { Bir kriz dönemi olarak ifade edebileceğimiz pandemi döneminde bireyler mizaha sarılarak } \\
\text { kolektif bir üretim ve paylaşım ağı oluşturmuştur. Bu ağ da beğeni ve yorumlar aracılığı ile } \\
\text { çok sayıda insan tarafından desteklenmiştir. Araştırmanın varsayımları doğrulanmıştır. }\end{array}$ \\
\hline Ar-02 & $\begin{array}{l}\text { Depresyon ile sosyal medya bağımlılığı bir sarmal oluşturmuştur. Aralarında anlamlı bir } \\
\text { iliş̧ki vardır. Depresyonun sosyal medya bağlıı̆ına neden olacağı düşünülebilir. }\end{array}$ \\
\hline Ar-03 & $\begin{array}{l}\text { THY, Covid-19 sürecinde çeşitli reklam kampanyaları ile Kriz iletişimi yöntemi kullanmış } \\
\text { ve bireylerin duygularına hitap etmiştir. Eski film müzikleri ile bağ oluşturmuş ve } \\
\text { krizlerin birgün bitip eski neşeli günlere dönüleceği algısı oluşturulmuştur. }\end{array}$ \\
\hline Ar-04 & $\begin{array}{l}\text { Vaka sayılarının yükseldiği dönemlerde Sağlık Bakanlığı YouTube sayfasındaki paylaşımlara } \\
\text { yapılan yorumlar da artmıştır. Sağlık çalışanlarına karşı yüksek düzeyde pozitif ayrışma olduğu } \\
\text { anlaşılmıştır. Bakanlığın yorumlarda sorulan sorulara cevap vermediği tespit edilmiştir. }\end{array}$ \\
\hline Ar-05 & $\begin{array}{l}\text { Araştırmaya katılanlara göre koruyucu önlemlere uymada \%85-90 artış olmuştur. Hasta } \\
\text { olma kaygısının da süreçte yükseldiği anlaşılmıştır. Katılımcıların \%59'unda sosyal medya } \\
\text { kullanma isteği \%75'inde ise haber takip etme isteğinin yükseldiği ifade edilmiştir. }\end{array}$ \\
\hline Ar-06 & $\begin{array}{l}65 \text { yaş üstü sokağa çıkma yasağı kapsamında "Ekli Sözlük" platformunda yaşlılara küfür, hakaret } \\
\text { içeren ve onları itlaf edilmesi gerekenler olarak gösteren yorumlar yapıldığı görumlmştür. }\end{array}$ \\
\hline Ar-07 & $\begin{array}{l}\text { Markalar sosyal medyada salgınla ilgili paylaşımlar yapmıştır. Fakat paylaşımların ağırlığı } \\
\text { ürünlere ulaşımla ilgilidir. Sağlık çalışanlarına teşekkür gibi paylaşımlar \%3’lerde kalmıştır. } \\
\text { Fakat bu paylaşımların etkileşim oranları diğer paylaşımlara göre çok daha yüksek } \\
\text { olmuştur. Yorumlarda ise sıklıkla tüketiciler markalardan destek talep etmiştir. }\end{array}$ \\
\hline Ar-08 & $\begin{array}{l}\text { Sağlık alanındaki kanaat önderleri sosyal medyadaki infodeminin önüne geçecek } \\
\text { kadar etkin bir strateji izleyememektedir. Halkın ne yaşanıyor? Nasıll yürütülüyor? } \\
\text { Ve nasıl mücadele etmeliyim? Sorularına cevap bulunamadığı görülmüştür. }\end{array}$ \\
\hline
\end{tabular}




\begin{tabular}{|c|c|}
\hline Kod & Sonuçlar \\
\hline Ar-09 & $\begin{array}{l}\text { Devlet kurumları sosyal medyanın önemini fark etmiştir ve kriz durumlarında etkin } \\
\text { kullanmaktadır. Türkiye Sağlık Bakanlığı, Twitter paylaşımlarının \%74'ünde bilgi } \\
\text { aktarmış, \%63 oranında gözetim izleme ve durum farkındalıklarını sağlamakta kullanmış, } \\
\% 53 \text { ile de kriz ve riskler bağlamında kamu bilinci artırmada kullanmıştır. }\end{array}$ \\
\hline Ar-10 & $\begin{array}{l}\text { Dijital ortamın kontrolsüz ve denetimsiz yapısı Covid-19 sürecinde misenformatik ve dezenformatik } \\
\text { iletilerin yoğun görülmesine neden olmaktadır. Ayrıca hesap hacklenmeleri ve sahte hesap açmalar } \\
\text { da süreci olumsuz etkilemektedir. Kullanıcıların içerikleri değiştirebilme yetkisi de suçların tespitini } \\
\text { önlemektedir. Covid-19 sürecinin ilk evresinde bu durumlar görülmüştür. Süreçte sosyal ağlar } \\
\text { daha aktif kullanılmış ve psikolojik sarsıntı nedeniyle özensiz paylaşımlar sık gerçekleşmiştir. }\end{array}$ \\
\hline Ar-11 & $\begin{array}{l}\text { WhatsApp gibi kapalı sosyal ağlarda yalan haberler çok hızlı yayılmakta, } \\
\text { doğrulama platformları yayılan bu bilgilerin çoğunun yanlış olduğunu ortaya } \\
\text { koymaktadır. Yalan-yanlış haber salgın kadar tehlikeli bir durumdur. }\end{array}$ \\
\hline Ar-12 & $\begin{array}{l}\text { \#Hayatevesığar ile Sağlık Bakanlığı sosyal medyayı aktif kullanmış ve doğru bilgileri } \\
\text { aktarmıştır. Evde zaman geçirmenin önemi izah edilmiştir. İncelemede Sağlık Bakanlığı'nın ikon } \\
\text { kullanarak bilginin kendisine ait olduğunu göstermesi bilgi güvenliği açısından önemlidir. }\end{array}$ \\
\hline $\operatorname{Ar}-13$ & $\begin{array}{l}\text { Verilere göre firmalar salgın döneminde sosyal medyayı daha aktif ve tüketici merkezli } \\
\text { kullanmıştır. Ağırlıklı olarak kriz sürecine uygun tasarlanmış paylaşımlar aktarılmıştır. }\end{array}$ \\
\hline Ar-14 & $\begin{array}{l}\text { Katıımcıların bir kısmı dua ve tevekkül ile salgın ile başa çıkma eğilimindeyken bazı katıımcılar ise } \\
\text { seküler yöntemlerle başa çıkmaya çalışmıştır. Birkaç kişi ise günlük değişen eğilimler sergilemiştir. } \\
\text { Genel olarak bakıldığında yardımlaşma, içsel muhasebe, hayatı sorgulama eğilimleri yükselmiştir. }\end{array}$ \\
\hline Ar-15 & $\begin{array}{l}\text { Salt kar amaçlı pazarlama mantığı geçerliliğini yitirmiş, değer temelli bir eğilim } \\
\text { başlamıştır. GSM operatörleri de bağ güçlendirme eğilimini artırmıştır. YouTube } \\
\text { reklamlarının çoğunda sosyal mesaj paylaşılmıştır. Salgın temaları işlenmiştir. }\end{array}$ \\
\hline Ar-16 & $\begin{array}{l}\text { Sağlık Bakanı'nın paylaşımları büyük ilgi görmüştür. Bakan'ın takipçi sayısı } 12 \\
\text { kart artmıştır. Bakan paylaşımlarında hashtag fazla kullanmayan bakan Koca, } \\
\text { genellikle paylaşımlarını da mobil cihaz üzerinden gerçekleştirmiştir. }\end{array}$ \\
\hline Ar-17 & $\begin{array}{l}\text { Doğrulama platformları salgın ile ilgili birçok hatalı bilginin kontrolünü gerçekleştirmiştir. Teyit sitelerinde } \\
\text { ve sitelerin sosyal medya hesaplarında etkileşim çok artmıştır. Sadece Türkiye ile değil küresel olarak } \\
\text { da yayılan hatalı bilgiler sorgulanmıştır. Sorgulamalarda komplo teorileri de büyük yer tutmuştur. }\end{array}$ \\
\hline
\end{tabular}

Araștırmaların elde ettiği sonuçları çeșitli başlıklar altında birleștirebiliriz. Böylece ulaşılan sonuçların daha genel bir değerlendirmesini yapmamız kolaylaşacaktır. İncelenen araştırmaların psikolojik değerlendirmeleri ele alındığında sürecin insanlar üzerinde bıraktığı etki daha rahat anlaşılacaktır.

Araştırmaların sonuçları analiz edildiğine dikkat çeken ilk nokta, yaşanılan pandemi sürecinin insanlarda çeşitli değişikliklere neden olduğunun tespitidir. Ar-01 pandemi sürecinde izolasyon yaşayan insanların bu sürecin olumsuz yönlerini azaltmak ve sosyalleşme ihtiyacını karşılamak için mizah öğelerine yöneldiklerini ve bu süreçte mizahi paylaşımlardaki etkileşimlerin arttığını gözler önüne sermiştir. Ar-02, pandemi sürecinin psikolojik etkisini daha açık ortaya sermek adına 211 katılımcılı bir çalışma gerçekleştirmiştir. Çalışmada elde edilen verilerle pandemi sürecinde evde kalan bireyin sosyal medya bağımlılığının arttığını ve sosyal medya bağımlılığı ile depresyon arasında anlamlı bir ilişki olduğunu aktarmıştır. Ar-02'nin ulaştığı bu sonuç, aynı zamanda Ar-04 deki bulgularla da örtüştügü görülmektedir. Vaka sayılarının yükseldiği, yani insanların daha fazla korku ve panik içinde oldukları dönemlerde Sağlık Bakanlığı'nın YouTube kanalındaki etkileşim oranlarının yükselmesi de Ar-01 ve Ar-02'nin de üzerinde durduğu pandemi sürecinin psikolojik etkileri arasınadır. Ar-05, Ar-02 de olduğu gibi katılımcılar üzerinde bir araștırma gerçekleștirmiștir. Fakat Ar-05 diğer çalıșmalardan daha geniş bir sonuca ulaşmış ve diğer çalışmaları destekleyen veriler ortaya koymuştur. Ar-05'in, 520 kişinin katılımıyla oluşan araştırmasının sonuçlarına göre hasta olma kaygısında ciddi bir yükselme olduğu görülmüştür. Kaygı düzeyinin yükselmesi psikolojik bir etki olarak değerlendirildiğinde Ar-01, Ar-02 ve Ar-04'ü desteklediğini ifade edebiliriz. Ayrıca Ar- 
05'in ulaştığı bir diğer önemli sonuç da Ar-04, Ar-01 ve Ar-02'de kısmen bahsedilen pandemi sürecinde sosyal medya kullanma isteğinin arttığı sonucudur.

Çalışmalardaki psikolojik sonuçlar bu kadarla sınırlı değildir. Ar-06'da değinilen konunun da psikolojik etkilerini yok saymak doğru bir sonuca ulaşmamızı engelleyecektir. 65 yaş üstü kişilere karşı nefret söylemlerinin oluşması, toplumsal psikolojinin aktarılması açısından oldukça önemlidir. Ar-07, Ar-13 ve Ar-15'in elde ettiği sonuçlardaki markaların sürece uygun mesajları ve sağlık çalışanlarını destekleyen söylemlerinin aktarıldı̆̆ı mesajların daha fazla etkileşim alması da yine sürecin psikolojik etkisini açıklar niteliktedir. Son olarak Ar-14'ün ulaştığı sonuca da değinmek gerekir. Ar-14'e göre süreçle başa çıkmada bazı bireyler dua ve tevekkül yöntemlerini tercih etmektedir. $\mathrm{Bu}$ yöntemler de sürecin insanlar üzerinde bıraktığı psikolojik etkiyi göstermesi açısından önemlidir.

Sonuçlarda ulaşılan bir diğer önemli konu başlığı ise bilgi ihtiyacıdır. İnsanların süreç ile ilgili bilgi alma ihtiyacı ve yetkililerin ise insanlara doğrudan ulaşma ihtiyacı süreç içinde sosyal medyanın bilgi akışında daha etkin kullanılmasını sağlamıştır.

İncelenen araştırmalara göre insanların haber alma ihtiyacı pandemi süreci içerisinde artış göstermiştir. Ar-05'e göre katılımcıların \%75'i haber alma isteklerinde artış olduğunu ifade etmiştir. Ar-09'a göre devlet kurumları sürecin önemini izah etmekte sosyal medyayı sıklıkla kullanmıştır. Sağlık Bakanlığı'nın Twitter hesabının kullanımı değerlendirildiğinde \%74'lük bir oranda bilgi aktarıldığı tespit edilmiştir. Ayrıca yine aynı çalışmada \%53 oranında kriz ve riskler bağlamında kamu bilincini artırmaya yönelik paylaşımların olduğu da görülmüştür. Ar-12'ye göre Sağlık Bakanlığı'nın uygulaması olan "Hayat Eve Sığar" ile Sağlık Bakanlığı insanlara doğru bilgiyi ulaştırmayı amaçlamıştır. Ayrıca Ar-16'nın sonuçlarını da bu kapsamda değerlendirdiğimizde insanların doğru bilgiyi, temel kaynaktan alabilmek için Sağlık Bakanı Fahrettin Koca'nın Twitter hesabını takip ettiklerini ve pandemi sürecinde Koca'nın takipçi sayısının 12 kat yükseldiği aktarılmıştır. Son olarak bilgi ihtiyacını karşılama ile ilgili aktarılması gereken önemli bir nokta da Ar-04'ün ifade ettiği bakanlığın yorumlarda sorulan sorulara cevap vermemesi durumudur. İnsanların cevaba ihtiyaç duyduğu bir dönemde bakanlığın sorulara cevap verip doğru bilgi kaynaklarına yönlendirmesi önem arz etmektedir.

Bilgi ihtiyacının yükselmesi süreçte yanlış ve eksik bilgilerin dolaşımına da neden olmaktadır. Sosyal medyadaki bilgilerin kontrolü ve mesajların suç öğeleri barındırıp barındırmadığının kontrolü süreç içinde çeşitli çalışmalarla analiz edilmiştir.

Ar-08, doğrudan infodemi konusuna eğilmiş ve infodeminin önlenmesi için çeşitli tavsiyelerde bulunmuştur. Ar-10, misenformatik ve dezenformatik iletilerde yaşanan yoğunluktan ayrıca hacklenmeler ve sahte hesaplarla yayılan kötü amaçlı bilgilerden bahsetmiştir. Ar-11 hatalı bilgilerin yayılmasında WhatsApp gruplarının önemine değinmiş ve yalan-yanlış haberin salgın kadar önemli sorunlar ortaya çıkardığını aktarmıştır. Ar-11 ile Ar-17 ayrıca doğrulama platformlarının önemini ifade ederek bu platformların süreçte etkin kullanılması gerektiği yönünde görüş aktarmıştır. Ar-10’un ifade ettiği kullanıcıların içerikleri istedikleri zaman değiştirebilme ihtimali de bilgilerin güvenilirliğinin kontrolünü zora sokan bir durumdur.

Çalışmalarda aktarılan sonuçlarda değinilmesi gereken iki önemli nokta daha vardır. Ar-03, insanların duygularına hitap eden, bir gün kriz bitecek ve eski günlere döneceğiz temalarının önemini aktarırken, Ar-05 sosyal medya aracılığı ile alınan bilgilerin 
katılımcıların tedbirlere uyması noktasında ciddi artışlar sağladığını aktarması sosyal medyanın insanlar üzerindeki etkisini göstermek adına önemlidir.

Tablo 5. Yapılan Araştırmalarda Daha Sonraki Çalışmalara Öneriler

\begin{tabular}{|c|c|}
\hline Kod & Öneriler \\
\hline Ar-01 & - \\
\hline Ar-02 & $\begin{array}{l}\text { Gelecekte, farklı bağımsız değişkenlerle Covid-19 salgınının üniversite öğrencilerinin } \\
\text { depresyon düzeyinde kalıcı bir etki bırakıp bırakmadığı incelenmelidir. }\end{array}$ \\
\hline Ar-03 & - \\
\hline Ar-04 & $\begin{array}{l}\text { Sosyal medya ile ilgili çalışmalar analiz edildiğinde YouTube ile ilgili yapılan } \\
\text { çalışmaların az olduğu gözlemlenmiştir. Daha sonra yapılacak çalışmalarda, daha } \\
\text { önce yapıımış çalışmaların sonuçlarının karşılaştırılması tavsiye edilmiştir. }\end{array}$ \\
\hline Ar-05 & $\begin{array}{l}\text { Yapılan çalışma sosyal medya etki alanı ile sınırlıdır. Yeni çalışmalar daha farklı etki } \\
\text { alanını incelemeli ve Covid-19'un toplum ruh ve sağlık açıları değerlendirilmelidir. }\end{array}$ \\
\hline Ar-06 & - \\
\hline Ar-07 & - \\
\hline Ar-08 & $\begin{array}{l}\text { Daha sonra yapılacak araştırmaların kanaat önderlerinin mesaj içerikleri } \\
\text { ve anlamsal yapıları üzerine yapılması vurgulanmıştır. }\end{array}$ \\
\hline Ar-09 & - \\
\hline Ar-10 & - \\
\hline Ar-11 & - \\
\hline Ar-12 & - \\
\hline Ar-13 & - \\
\hline Ar-14 & - \\
\hline Ar-15 & - \\
\hline Ar-16 & $\begin{array}{l}\text { Kamu otoritelerinin kriz döneminde sosyal medyayı nasıl kullandığını araştıran bu çalışmayı } \\
\text { tamamlayıcı olarak kullanıcıların görüş, kanaat ve etkileşim davranışlarını belirlemeye } \\
\text { yönelik araştırmalar yapılması konun daha aydınlatılmasını sağlayacaktır. }\end{array}$ \\
\hline Ar-17 & $\begin{array}{l}\text { Pandemi sürecinde yayılan hatalı bilgiler ile ilgili araştırmaların yapılması infodeminin önlenmesi } \\
\text { adına önemlidir. Benzer çalışmalar kriz enformasyonu sorununa da katkı sağlayacaktır. }\end{array}$ \\
\hline
\end{tabular}

İncelenen araştırmalarda daha sonra yapılacak çalışmalar için önerilerin az olduğu görülmüştür. 17 araştırmanın sadece 6 tanesinde öneri olması oldukça az bir rakamdır. Sosyal bilimlerde araştırmaların sonuç bölümünde önerilerde bulunmak, bir gelenek haline gelmiştir (Dinler, 2016, s. 107). Önerilerle diğer araştırmacılara yol gösterilir. Konu ile ilgili incelenmeyen ve ya incelenemeyen değişkenler ifade edilerek yeni çalışmalara bilgi aktarılır (Küçük, 2016, s. 146). Bu bağlamda öneriler değerlendirildiğinde Ar02 ve Ar-05'in, sosyal medya ve psikolojik etkileri konusunda araştırmacıları yeni araştırmalar yapmaya teşvik edici bir öneride bulunduğu görülmüștür. Ar-04 sosyal medya mecralarının incelenmesindeki dengesizlikten bahsederek YouTube üzerine yapılan çalışmaların biraz daha artırılmasını tavsiye etmiştir. Ayrıca daha önce yapılan çalışmaların sonuçlarının da karşılaştırılmasının fayda getireceğini vurgulamıştır. Ar08 kanaat önderlerinin mesajlarının anlamsal yapıları üzerinde durulmasını aktarmıș, Ar-16 ise aynı konu ile alakalı kamu otoritelerinin sosyal medyayı kullanım şekillerinin incelenmesini ve etkileșim davranışlarını belirlemeye yönelik çalıșmaların artırılmasını tavsiye etmiştir. Ar-17 kriz enformasyonuna katkı amaçlı infodeminin önlenmesi konusuna eğilmeyi araştırmacılara tavsiye etmiştir.

\section{Sonuç ve Öneriler}

Covid-19 sürecinin sosyal medyaya yansımasını ele alan 17 araştırma; amaç, yöntem ve sonuçları açısından literatüre farklı katkılar sağlamıștır. Bu çalışmada, ortak özellikleri 
olan pandemi süreci ve sosyal medya alanını ele almalarından yola çıkarak amaçları, sonuçları ve önerileri açısından birlikte yorumlanmıştır. Bu yorumlama total bir sonuca ulaşma çabasıdır. Sosyal medyadaki Covid-19 sürecinin ele alınıșını incelemek ve aynı alan, konu üzerine çalışma yapmak isteyen araştırmacılara bir rehber oluşturulmak istenilmiştir. Araştırmaların total değerlendirmelerini gören araștırmacılar, yeni araştırmalarda ele alınması gereken konuları ve konuların değerlendirilmesi gereken yönlerini daha rahat görebilecektir.

Çalışmaların incelenmesinde ilk dikkat çeken nokta çalışma deseni olarak nitel, nicel ve karma yöntemlerin dengeli dağılımının olmasına rağmen, inceleme yöntemi açısından içerik analizinin ağırlıklı kullanılmasıdır. Sosyal medya çalışmalarında içerik analizi dışında başka yöntemlerin de daha sık kullanılması gerektiği düşünülmektedir. İnceleme alanı olarak Twitter, Instagram ve YouTube'un faklı çalışmalarda incelendiği görülse de Facebook'un hiçbir çalışmanın ana inceleme alanı olmaması dikkat çekmiştir. Oysa Hootsuite'nin 2020 verilerine göre Türkiye'de en çok kullanılan sosyal medya platformlarında Facebook, dördüncü sıradadır ve Twitter'in önündedir (https:// dijilopedi.com, 2021). Bu duruma rağmen Facebook'un ana inceleme sahası olamaması bir eksikliktir. Yapılan 17 çalışmanın sadece ikisinde kullanıcılara yönelik saha çalışması yapılması süreçteki kullanıcı düşüncelerinin çalışmalara tam anlamı ile yansımamasına neden olacaktır. Doğrudan kullanıcılara yönelik yapılacak çalışmalara daha fazla ihtiyaç duyulduğu düşünülmektedir.

Çalışmaların amaçlarını incelediğimizde dört temel amacın varlığı görülmüştür;

- Sosyal meyanın kullanım şekillerini analiz etmek

- Sosyal medya paylaşımlarındaki etkileşimleri analiz etmek

- Sosyal medya paylaşımları ile bireylerin psikolojik durumları arasındaki bağlantıyı analiz etmek

- Sosyal medya paylaşımlarının doğruluğu ile ilgili durumu analiz etmek

$\mathrm{Bu}$ amaçlar oldukça önemlidir. Fakat günümüzün en önemli iletişim aracı olan sosyal medyayı anlamak ve doğru analiz etmek için yeterli olduğu düşünülmemektedir. Özellikle, Covid-19 pandemisi gibi uluslararası bir sağlık krizini yorumlamak için daha fazla çalışmaya ve beraberinde daha farklı amaçlara yönelmiş çalışmalara ihtiyaç vardır.

İncelenen araştırmaların sonuçları değerlendirildiğinde ise öne çıkan üç temel sonuca ulaşıldığı gözlemlenmiştir:

- Pandemi sürecinin insanlarda değișimlere neden olduğu

- Pandemi sürecinde bilgi ihtiyacının arttığı

- Pandemi sürecindeki yanlış ya da eksik bilgilerin sorunlara neden olduğu

Elde edilen bu üç genel sonuç pandemi sürecindeki sosyal medya kullanımlarının açılklanmasında önemli bir veri elde etmemizi sağlamaktadır. Fakat sürecin sosyal medya ile ilişkisinde aydınlatılması gereken çok daha fazla nokta vardır. $\mathrm{Bu}$ noktalar aydınlatılmadan Covid-19 sürecindeki sosyal medya araștırmalarının nihayete eremeyeceği düşünülmektedir.

İncelenen araştırmalarda yapılacak yeni çalışmalara öneriler de ele alınmış ve bu öneriler doğrultusunda yeni çalışmaların şekillendirilmesi tavsiye edilmiştir. Fakat incelenen araștırmaların sadece 6 tanesinde öneri bulunması yeni araştırmalara yol gösterme 
adına oldukça düşüktür. Yapılan yeni çalışmalarda öneriler kısmına önem verilmesi araştırmacılara tavsiye edilmektedir. Araştırmaların üzerinde durduğu öneriler;

- Sosyal medyanın psikolojik etkileri konusunda daha fazla analiz yapılması

- Kanaat önderlerinin mesajlarının anlamsal yapılarının araştırılması

- Kamu otoritelerinin sosyal medyayı kullanım şekillerinin incelenmesi ve etkileşim davranışlarının analizi

- İnfodeminin önlenmesine yönelik çalışmaların artırılması

- Yapılan çeşitli araştırmaların sonuçlarının karşılaştırılması

Elde edilen bulgulardan yola çıkarak konu ile ilgili gelecekteki araştırmalara yol göstermek için aşağıdaki konuların da ele alınması gerektiği ifade edilebilir:

- Covid-19 virüsüne maruz kalmışlara karşı yapılan ötekileștirmeler üzerine araștırmalar

- İnsanları galeyana getiren paylaşımların oluşturduğu etkileri ölçen araştırmalar

- İzolasyon sürecinin toplum yapısında meydana getirdiği değişimlerin sosyal medyaya yansımasını ele alan araştırmalar

- Pandemi sürecinin sosyal medyanın e-ticaretteki rolünde oluşturduğu etkiyi ele alan araştırmalar

- Pandemi sürecinin hayatımıza soktuğu online konser, tiyatro, sinema gibi yeni sosyal aktivitelerin, sosyal medya yansımalarını ele alan araștırmalar

- İzolasyon sürecinde psikoloji ile ilgili yaşanan değişimlerin sosyal medya yansımalarını ele alan araştırmalar

- Pandemi süreci ile beraber sosyal medyanın online eğitim sürecindeki rolünü ele alan araştırmalar

- Sağlık emekçilerinin süreç ile ilgili paylaşımlarını ele alan araştırmalar

- Süreçten en çok etkilenen gruplardan olan çocukların sosyal medya ile ilişkisini inceleyen araştırmalar

- Çocuklara yönelik hazırlanmış pandemi konulu sosyal medya iletilerinin çocuklardaki etkilerini ele alan araştırmalar

- Sosyal medyada aktarılan bilgilerin güvenilirliğini artırmaya yönelik öneriler geliştiren araștırmalar

- Pandemi sürecinde sosyal medyada yabancılara karşı oluşturulan korku ve nefret söylemlerinin ele alındığı araştırmalar

- Pandemi süreci ve slaktivizm gibi yeni akımların ilişkilerinin ele alındığı araştırmalar

- Sağlık alanındaki bilgilerin paylaşımı için sosyal medya platformlarının yapılarının uygunluğunu ele alan araştırmalar

Ayrıca bir başka öneri de sosyal bilimler alanında çalışmaları birleştiren ve total bir değer elde edilmesini sağlayan, böylece karmaşıklığı gideren meta-sentez yöntem ile yapılan çalışma sayısını artırmaktır.

\section{Notlar}

1 Her geçen gün internet ve sosyal medyaya daha fazla zaman ayrılmaktadır. Internet World Stats'ın raporuna göre 2021yılı ilk çeyreğinde dünya nüfusunun \%64,2'sinin internet erişimi vardır. Tabi ki erişim dünya üzerinde dengeli bir dağılıma sahip değildir. Amerika nüfusun \%95'ının ve Avrupa'da ise \%87.7'sinin internet erişimi varken, en düşük erişime sahip olan Afrika'da bu oran \%43'lere düşmektedir. Türkiye'de ise internet erişimi \%83.3 olarak görülmektedir (https://www. 
internetworldstats.com, 2021). Türkiye istatistik kurumu 2020 yılı rakamlarında internet erișimi olan hane oranını $\% 90.7$ olarak belirtmiş̧ir (data.tuik.gov.tr, 2021). 2019 0cak verilerine göre Türkiye'de 54 milyon kişi sosyal medya kullanıcıdır. Bu rakam da ortalama Türkiye nüfusunun \%64'üne denk gelmektedir (www.bbc.com, 2021). Tüm bu rakamlar internet kullanımının ve beraberinde sosyal medyanın artık çok yoğun kullanıldığını ve toplum yaşamında sosyal medyanın önemli bir yer kapladığını göstermektedir.

2 İnternette gözümüze ilişen birçok haber ve bilginin kaynağı belli değildir. Viral kanallarla sıradan insanların görüş ve kanaatlerinin yaygınlaşması medyanın yatay bir eksende büyümesini sağlamışıı. Yeni dönemin, yeni bilgi kaynağı olan sanal dünya, alışılagelmiş yöntemlerle elde edilen bilginin kalıplarıın yıkıldığı bir devrim olsa da aynı zamanda kendi karşı devrimini de getiren bir yöntem olarak karşımıza çıkmaktadır (Uzunoğlu, 2017; Karagöz, 2018, s. 685).

3 Analiz kavramı anlam olarak kod çözümlemeyi ifade ederken, sentez ise anlam olarak birleştirmek demektir (Dinçer, 2018, s. 180). Fakat meta-sentez ile meta-analiz kavramları birçok kaynakta eşdeğer anlamda kullanılmışıtır. Bazlı kaynaklarda nitel meta-analiz olarak ifade edildiği görülmüştür. Bu farkı isimlendirmeler aynı anlamı ifade etmektedir (Paterson vd. 2001; Park \& Gretzel, 2007, s. 48). Çalışmada kullandığımız kaynaklarda yöntemin ismi olarak meta-analiz veya metasentez ifadelerinin hangisini kullandığından ziyade nitel ya da nicel çalışmayı aktarması dikkate alınmıştır. Nicel çalışmaların ifadeleri meta-analiz, nitel çalışmaların ifadeleri meta-sentez olarak düzenlenip aktarılmışıır.

4 To put it in numbers, (on 01/02/2021) when Google scholar was scanned with the keyword "Covid-19", about 3,500,000 data were encountered. 15,200 data was seen when we searched the keyword "digital media" along with "Covid-19", 12,700 when we searched the keyword "new media", 1,280 when we searched "social media"

\section{Kaynakça}

Akgül, M. (2020). Çevrimiçi Ortamlarda Nefret Söylemi: Ekşi Sözlük'te 65 Yaş Üstü Sokağa Çıkma Yasağı Tartışmaları. İletişim Kuram ve Araştırma Dergisi, (51), 57-78.

Akyüz, S. S. (2020). Yanlış Bilgi Salgını: COVID-19 Salgını Döneminde Türkiye'de Dolaşıma Giren Sahte Haberler. Akdeniz Üniversitesi İletişim Fakültesi Dergisi, (34), 422-444.

Alemdaroğlu, A., \& Demirtaş, N. (2004). Mynet'te Erkeklik Halleri. Toplum ve Bilim(101), 206-225.

Arğın, E. (2019). Z Kuşağının Sosyal Medya Bağlılığı ve Narsist Eğilimler: Elazı̆̆ İli Örneği. Avrasya Sosyal ve Ekonomi Araştırmaları Dergisi, 6 (6), 166-183.

Ateş, N. B., \& Baran, S. (2020). Kriz İletişiminde Sosyal Medyanın Etkin Kullanımı: Covid-19 (Koronavirüs) Salgınına Yönelik Twitter Analizi. Kocaeli Üniversitesi İletişim Fakültesi Araştırma Dergisi, 64-96.

Aydın, A. F. (2020). Post-truth Dönemde Sosyal Medyada Dezenformasyon: Covid-19 (yeni koronavirüs) Pandemi Süreci. Asya Studies, 4 (12), 76-90.

Babacan, M. E. (2014). Sosyal Medya Sonrası Yeni Toplumsal Hareketler. Birey ve Toplum Sosyal Bilimler Dergisi, 4 (1), 135-160.

Babacan, M., Hașlak, İ., \& Hira, İ. (2011). Sosyal Medya ve Arap Baharı. Akademik Incelemeler Dergisi, 6 (2), 63-92.

Bahar, A. (2020). Polislik Perspektifinden Dijital Misenformasyon ve Dezenformasyon: Covid-19 Örnek Olayı Bağlamında Bir Analiz. OPUS Uluslararası Toplum Araştırmaları Dergisi, 16 (30), 2760-2794.

Bilgiç, A., \& Akyüz, S. S. (2020). Türkiye'de Covid-19 Pandemisi Döneminde Sağlık Bakanı Fahrettin Koca'nın Sosyal Medya Kullanımı: Twitter Paylaşımları İçerik Analizi. Gaziantep Üniversitesi Sosyal Bilimler Dergisi, 19(COVID-19 Special Issue), 230-243.

Binark, M. (2014). Giriş. M. Binark (Dü.) içinde, Giriş, Yeni Medya Çalışmalarında Araştırma Yöntem ve Teknikleri. İstanbul: Ayrıntı Yayınları. 
Bode, L., \& Vraga, E. K. (2018). See Something, Say Something: Correction of Global Health Misinformation on Social Media. Health communication, 33 (9), 1131-1140.

Chou, S. W.-y., Hunt, Y. M., Beckjord, B. E., Moser, R. P., \& Hesse, B. W. (2009). Social media use in the United States: Implications for health communication. Journal of Medical Internet Research, 11(4), 1-12.

Cılızoğlu, G. Y., Dondurucu, Z., \& Çetinkaya, A. (2020). Sosyal Pazarlama Bağlamında Covid-19 Salgını Sürecinde GSM Operatörlerinin Youtube Reklamlarının Analizi. Uluslararası Kültürel ve Sosyal Araştırmalar Dergisi (UKSAD), 6 (1), 280-299.

data.tuik.gov.tr. (2021, 01 25). https://data.tuik.gov.tr/Search/Search?text=sosyal\%20 medya\&dil=1 adresinden alındı

Depoux, A., Martin, S., Karafillakis, E., Preet, R., Wilder-Smith, A., \& Larson, H. (2020). he pandemic of social media panic travels faster than the COVID-19 outbreak. Journal of Travel Medicine(27), 1-2.

Dikmen, M. (2021). COVID-19 Pandemisinde Üniversite Öğrencilerinin Depresyon Düzeyleri ile Sosyal Medya Bağımlılıkları Arasındaki İlişki: Bir Yapısal Eşitlik Modeli. Bağımlılık Dergisi, Journal of Dependence, 22 (1), 20-30.

Dinçer, S. (2018). Content Analysis in Scientific Research: Meta-Analysis, Meta-Synthesis, and Descriptive Content Analysis. Bartın University Journal of Faculty of Education, 7 (1), 176-190. doi:DOI: 10.14686/buefad.363159

Dinler, Z. (2016). Bilimsel Araştırma ve a-kaynaklar. Bursa: Ekin Yay.

Evers, C. W., Albury, K., Byron, P., \& Crawford, K. (2013). Young people, social media, social network sites and sexual health communication in Australia: This is funny, you should watch it. International Journal of Communication, 7(18), 263-280.

Fauci, A., Lane, H. C., \& Redfield, R. R. (2020). Covid-19 navigating the uncharted. The new england journal of medicine, 1268-1269.

Field, A. P., \& Gillett, R. (2010). How to do a meta-analysis. British Journal of Mathematical and Statistical Psychology, 63.3, 665-694.

Gao, J., Zheng, P., Jia, Y., Chen, H., Mao, Y., Chen, S., \& Daj, J. (2020). Mental health problems and social media exposure during COVID-19 outbreak. Plos one, 15 (4), 1-10.

Geray, H. (2004). Toplumsal Araştırmalarda Nicel ve Nitel Yöntemlere Giriş. Ankara: Siyasal Kitapevi.

Güçlü, İ. (2019). Sosyal Bilimlerde Nitel Araştırma Yöntemleri Teknik, Yaklaşım Uygulama. Ankara: Nobel.

Hazar, Ç. M. (2011). Sosyal medya bağımlılığı-bir alan çalışması. İletişim Kuram ve Araştırma Dergisi, (32), 151-175.

https://dijilopedi.com. (2021, 01 28). https://<dijilopedi.com/2020-turkiye-internetkullanimi-ve-sosyal-medya-istatistikleri/ adresinden alındı

Karagöz, K. (2018). Post Truth Çağında Yayıncılığın Geleceği. TRT Akademi, 3 (6), 678708.

Karataş, Z. (2020). COVID-19 Pandemisinin Toplumsal Etkileri, Değişim ve Güçlenme. Türkiye Sosyal Hizmet Araştırmaları Dergisi, 4 (1), 3-17. 
Kavaklı, N. (2019). Yalan Haberle Mücadele ve İnternet Teyit/Doğrulama Platformları. Erciyes İletişim Dergisi, 6 (1), 663-682.

Kırık, A. M. (2017). Yeni Medya Aracılığıyla Değișen İletişim Süreci: Sosyal Paylaşım Ağlarında Gençlerin Konumu. Gümüşhane Üniversitesi İletişim Fakültesi Elektronik Dergisi, 5 (1), 230-261.

Kirman, F. (2020). Sosyal Medyada Salgın Psikolojisi: Algı, Etki ve Başa Çıkma. Dünya Insan Bilimleri Dergisi, (2), 11-44.

Kirtiş, K., \& Karahan, F. (2011). To Be or Not to Be in Social Media Arena as the Most Cost-Efficient Marketing Strategy after the Global Recession. Procedia-Social and Behavioral Sciences, 24, 260-268.

Koç, M. A. (2020). Covid-19 Salgınının Yarattı̆̆ı Küresel Kriz Bağlamında Sosyal Medyada Kriz Yönetimi: Türk Hava Yolları Örneği. Avrasya Sosyal ve Ekonomi Araştırmaları Dergisi, 7 (7), 190-200.

Korda, H., \& Itani, Z. (2013). Harnessing social media for health promotion and behavior change. Health promotion practice, 14 (1), 15-23.

Küçük, O. (2016). Bilimsel Araştırma Yöntemleri. Bursa: Ekin Yay.

Moorhead, A. S., Hazlett, D. E., Harrison, L., Carroll, J. K., Irwin, A., \& Hoving, C. (2013). A New Dimension of Health Care: Systematic Review of the Uses, Benefits, and Limitations of Social Media for Health Communication. Journal of Medical Internet Research, 14 (1), 1-17.

Naeem, M. (2021). Do social media platforms develop consumer panic buying during the fear of Covid-19 pandemic. Journal of Retailing and Consumer Services, 1-10.

Özoran, B. A. (2020). Covid-19 Salgınında Markaların Twitter Kullanımları Üzerine Bir İnceleme. Yüzüncü Yıl Üniversitesi Sosyal Bilimler Enstitüsü Dergisi, (Salgın Hastalıklar Özel Sayısı), 429-458.

Öztürk, M. F., \& Talas, M. (2015). Sosyal medya ve eğitim etkileșimi. Zeitschrift für die Welt der Türken/Journal of World of Turks,, 7 (1), 101-120.

Park, Y. A., \& Gretzel, U. (2007). Success Factors for Destination Marketing Web Sites: A Qualitative Meta-Analysis. Journal of travel research, 46 (1), 46-63.

Radwan, E., \& Radwan, A. (2020). The spread of the pandemic of social media panic during the COVID-19 outbreak. European Journal of Environment and Public Health, 4 (2), 1-3.

Sönmez, V., \& Alacapınar, G. F. (2019). Örneklendirilmiş Bilimsel Araștırma Yöntemleri (7 b.). Ankara: Anı Yayıncılık.

Subölen, S. (2020). Covid 19 Pandemisi Sürecinde Stresle Baş Etme Yöntemi Olarak Sosyal Medyada Mizah Olgusu: cezmikalorifer ve saykodelipaylasimlarr İsimli Instagram Hesaplarının Analizi. AJIT-e: Bilişim Teknolojileri Online Dergisi, 11.42, 123-142.

Şener, G. (2013). Önsöz. C. Bilgili, \& G. Șener (Dü) içinde, Sosyal Medya ve Ağ Toplumu 2 / Kültür, Kimlik, Siyaset (s. 5-14). İstanbul: Reklam Yaratıcıları Derneği.

Şimşek, V. (2018). Post-truth ve yeni medya: Sosyal medya grupları üzerinden bir inceleme. Global Media Journal TR Edition, 8 (16), 1-14. 
Tam, M. S. (2020). Covid-19 Süresince TC Sağlık Bakanlığı YouTube Kanalına İzleyici Dönütleri. Düşünce ve Toplum Sosyal Bilimler Dergisi, (3), 116-139.

Tanışık, S. (2020). Sosyal Medyada İçerik Üretiminin Markaların İtibarına Olan Etkisi: Covid-19 Pandemi Sürecinde Koç, Eczacıbaşı ve Arçelik'in Instagram Paylaşım Analizi. Avrasya Sosyal ve Ekonomi Araştırmaları Dergisi, 7 (6), 422-435.

Timulak, L. (2007). Identifying core categories of client-identified impact of helpful events in psychotherapy: A qualitative meta-analysis. Psychotherapy research, 305-314.

Timulak, L. (2009). Meta-analysis of qualitative studies: A tool for reviewing qualitative research findings in psychotherapy. Psychotherapy Research, 19 (4-5), 591-600.

Tunç, A. (2010). Tarihi Miras ve Güncel Beklentiler Arasındaki Türkiye. 23. Türk-Alman Gazetecilik Semineri, (s. 24250). Ankara.

Velavan, T. P., \& Meyer, C. G. (2020). The COVID-19 epidemic. Tropical medicine \& international health, 25 (3), 278-280.

Vural, A. Z., \& Bat, M. (2010). Yeni Bir İletişim Ortamı Olarak Sosyal Medya: Ege Üniversitesi İletişim Fakültesine Yönelik Bir Araştırma. Journal of Yasar University, 5 (20), 3348-3382.

www.bbc.com. (2021, 01 25). https://www.bbc.com/turkce/haberler-turkiye53259275\#: :text=Bu\%2C\%20internette\%20ge\%C3\%A7irilen\%20toplam\%20 s\%C3\%BCrenin,sosyal\%20medya\%20kulland\%C4\%B1\%C4\%9F\%C4\%B1\%20 anlam\%C4\%B1na\%20geliyor. adresinden alındı

www.bingol.edu.tr. (2021, 01 31). http://www.bingol.edu.tr/media/226858/saytbolum7a-Bilimsel-Arastirmalarda-Amac-Problem-ve-Sinirliliklar.pdf adresinden alındı

www.internetlivestats.com. (2021, 01 28). https://www.internetlivestats.com/ adresinden alındı

www.who.int. (2021, 01 26). https://www.who.int/csr/don/05-january-2020pneumonia-of-unkown-cause-china/en/ adresinden alındı

Yang, X., Yu, Y., Xu, J., Shu, H., Xia, H., Wu, Y., . . Shang, Y. (2020). Clinical course and outcomes of critically ill patients with SARS-CoV-2 pneumonia in Wuhan, China: a single-centered, retrospective, observational study. The Lancet Respiratory Medicine, 475-481.

Yeniçıktı, N. T. (2020). Sağlık Bakanlığının Instagram Paylaşımları Üzerinden Göstergebilimsel Bir İnceleme \#Hayatevesığar. Gaziantep Üniversitesi Sosyal Bilimler Dergisi (COVID-19 Special Issue), 365-385.

Yersel, B., Kalkan, B., \& Özer, A. Ç. (2020). Kim Paylaşıyor? İnfodeminin Önüne Geçmek için Alan Uzmanı Kanaat Önderlerinin Instagram Kullanımları ve Kullanıcı Etkileşimlerinin Analizi. Avrasya Uluslararası Araştırmalar Dergisi, 8 (24), 12-40.

Yılmaz, R. (2016). Öğretmenlerin İnternete Yönelik Epistemolojik İnançlarının İncelenmesi. (s. 966-979). Rize: 10th International Computer and Instructional Technologies Symposium (ICITS).

Yüksel, H. (2014). İnternet gazeteciliğinde bilgi kirliliği sorunu. Atatürk İletişim Dergisi, 125-138. 


\title{
Reflection of the Covid-19 Process on Social Media (A Meta-Synthesis Study)
}

\author{
İsmail Baydili (Lect. Ph.D.)
}

\section{Extended Abstract}

There is information about almost every area on social media. Now individuals can easily and quickly access the information they need. However, the practicality of social media in the production and distribution of information brings some disadvantages. Individuals who produce information can transfer information that is uncertain or contain partial errors as accurate. In addition, the possibility of sharing opinions or thoughts as information also poses a serious risk. In a very large stack of information, there will be great confusion when correct and incorrect information cannot be differentiated. Thus, verification platforms have been created to deal with such negative issues. However, a large segment of society does not have the technology literacy to actively use these platforms yet. Also, the adequacy of verification platforms is another area that needs to be examined.

The Covid-19 pandemic experienced in the world since the beginning of 2020 has shaken the current balance of the whole world and it has caused life to begin under new rules referred to as the new normal. Social media, the social life of the new way of life, has played a more active role in our lives in this period. Social media participation has increased, while the existing users have begun to spend even more time on it. Hence, information pollution on social media has affected much more people. The fear and panic experienced due to Covid-19 has grown even more with incomplete or inaccurate information from social media. According to some researchers, this situation is at least as dangerous as the disease itself.

This state of chaos has been studied by many researchers around the world and in Turkey. Important studies had been carried out on the subject. Social media messages in the Covid-19 period were discussed in many studies. A large number of studies addressing the relationship between the new media era and the Covid-19 period also cause confusion in the academic world. In order for new studies to be carried out to look at the unaddressed aspects of the subject and to focus on different goals, it is necessary to combine certain characteristics of the research that had already been done.

In this study, researches conducted in Turkey and in Turkish language were discussed. The discussed studies were evaluated together aimed at reaching a cumulative result. Hence, a guide is presented to the researchers, which presents the results of previous studies together and helps them in their subject and purpose selection.

Meta-synthesis method contained in qualitative pattern was selected to obtain cumulative data. This way, qualitative data of studies addressing the reflections of the Covid-19 period on social media was brought together. The researches obtained for the review was filtered through the "Dergipark" system. In addition, attention was paid to the presence of phrases such as Covid-19, new media, digital media, and social media in the keywords of the studies to be included. As a result of the search made with these criteria, 107 studies were examined in terms of title, summary and keywords. After the initial review, 32 studies were reviewed according to the inclusion criteria. As a result of the second 
review, 17 of the studies were found to be eligible. This study was carried out with 17 studies that fit the inclusion criteria.

In the classification, it was seen that the researches mainly aimed at the following objectives;

- To analyze the usage patterns of social media

- To analyze interactions in social media posts

- Analyzing the connection between social media posts and the psychological state of individuals

- To analyze the accuracy of social media posts

The studies examined were evaluated in terms of their results and it was seen that most of them reached the results below;

- The pandemic process is causing changes in people

- The need for information increased during the pandemic

- How incorrect or inaccurate information has caused problems in the pandemic period

Suggestions to guide new researches were also discussed in the study. According to the findings obtained in the evaluation, the following suggestions were found;

- Further analysis of the psychological effects of social media

- Investigation of the semantic structures of the messages of opinion leaders

- Examining the way public authorities use social media and analyzing their interaction behavior

- Increasing efforts to prevent infodemic

- Comparison of the results of various studies

In light of these data, when we briefly made a general assessment, it was observed that the content analysis method was mainly used in studies dealing with social media and the Covid-19 process. Although reviews of Instagram, YouTube, and Twitter were carried out sufficiently, Facebook was not mentioned in any study. It has also been observed that suggestions for new research were not made in many studies, and those that suggested it made so limitedly.

At the end of the study, 15 recommendations were made for new researches to be carried out in the future. Some of these recommendations are as follows;

- Examination of marginalization against those exposed to Covid-19 virus

- Examining the change that the pandemic period had created in the role of social media in e-commerce

- Addressing the social media reflections of new social activities such as online concerts, theater, cinema that the pandemic period has forced into our lives

- Conducting research on the role of social media in online education along with the pandemic process. 
- It is also recommended to use the meta-synthesis method, which combines the results of the studies, more frequently.

Keywords: Communication Sciences, Covid-19, Social Media, Meta-Synthesis, Health Communication.

Bu makale intihal tespit yazilımlarıyla taranmıştır. Intihal tespit edilmemiş̧tir.

This article has been scanned by plagiarism detection softwares. No plagiarism detected.

Bu çalışmada "Yükseköğretim Kurumları Bilimsel Araştırma ve Yayın Etiği Yönergesi" kapsamında uyulması belirtilen kurallara uyulmuştur.

In this study, the rules stated in the "Higher Education Institutions Scientific Research and Publication Ethics Directive" were followed.

Araşıırma tek bir yazar tarafından yürütülmüştür.

The research was conducted by a single author.

Çalışma kapsamında herhangi bir kurum veya kişi ile çıkar çatışması bulunmamaktadır.

There is no conflict of interest with any institution or person within the scope of the study. 